\title{
Estacionalidad en la industria cinematográfica española
}

JOSÉ ROBERTO VILA OBLITAS*

PAULA RODRÍGUEZ TORTOSA**

* Doctor. Departamento de Economía y Administración de Empresas. Universidad de Málaga, Málaga, España. E-mail: joseroberto@uma.es. ORCID: 0000-0003-0500-4724. Google Scholar: https://scholar.google.com/ citations? user $=$ dnfDt3UAAAAJ\&hl=es.

** Master en Marketing Digital. Universidad de Málaga, Málaga, España. E-mail: paulart_16@hotmail.com. ORCID: Google Scholar: https://scholar.google.es/citations?user=kzSSqywAAAAJ\&hl=es 


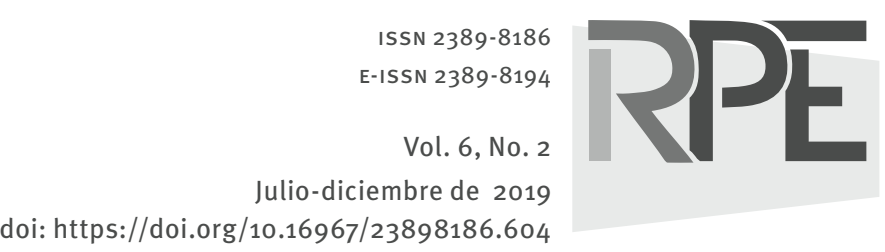

COMO CITAR ESTE ARTÍCULO

How to cite this article:

Vila, J.R. y Rodríguez, P. (2019). Estacionalidad en la industria cinematográfica española. Revista Perspectiva Empresarial, 6(2), 87-108.

Recibido: 08 de enero de 2019

Aprobado: 08 de julio de 2019
RESUMEN El presente trabajo analiza la estacionalidad existente en la industria cinematográfica española y estadounidense con la finalidad de poder realizar una comparativa entre estos países. En el análisis comparativo se utilizaron variables tales como fecha de estreno, la tendencia de las series y la variación en el número de espectadores. Para poder estudiar la estacionalidad, previamente se han definido las características propias de la industria en cada país. Se ha podido contemplar como la estacionalidad en las producciones españolas es más fuerte que la norteamericana. Además se aprecia como las fechas de estreno de las películas españolas no coinciden con el período en que los espectadores optan a más tiempo de ocio, mientras que en el caso norteamericano dichas fechas si coinciden con este período.

PALABRAS CLAVE estacionalidad, distribución cinematográfica, producción cinematográfica, industria cinematográfica, fecha de estreno.

\section{Seasonality in Spanish film industry}

ABSTRACT The present work analyzes the seasonality existing in Spanish and U.S. film industry with the aim of making a comparison between these two countries. The comparative analysis used variables such as release date, the trend of series and variation in the number of viewers. In order to study seasonality, the characteristics typical of the industry in each country were previously defined. It can be seen how seasonality in Spanish productions is stronger than the North American one. Besides, it is observed that release dates of Spanish movies do not coincide with the period viewers opt to have more leisure time, while in the case of North America, said dates do coincide with such period.

KEY WORDS Seasonality, film distribution, film production, film industry, release date. 


\section{Sazonalidade na indústria cinematográfica española}

RESUMO 0 presente trabalho analisa a sazonalidade existente na indústria cinematográfica espanhola e estadunidense com a finalidade de poder realizar uma comparativa entre estes países. Na análise comparativa se utilizaram variáveis tais como data de estreia, a tendência das séries e a variação no número de espectadores. Para poder estudar a sazonalidade, previamente se há definido as características próprias da indústria em cada país. Se há podido contemplar como a sazonalidade nas produções espanholas é mais forte do que a norte-americana. Ademais se aprecia como as datas de estreia dos filmes espanhóis não coincidem com o período em que os espectadores optam por mais tempo de ócio, enquanto que no caso norte-americano tais datas se coincidem com este período.

PALAVRAS-CHAVE sazonalidade, distribuição cinematográfica, produção cinematográfica, indústria cinematográfica, data de estreia. 


\section{Introducción}

Orbach y Einav (2007) apuntan que todas las películas que hay en el mercado compiten al mismo precio sin importar su procedencia o presupuesto. Asimismo, una película estadounidense compite al mismo precio que una europea. Esto quiere decir que el motivo que incita a un consumidor a ver un determinado tipo de película va más allá del precio de la entrada.

El éxito que tendrá una película no es fácilmente predecible puesto que este dependerá de aspectos tales como el reparto, la calidad, hacer una buena campaña publicitaria entre otros. Por ello el estudio de la estacionalidad sirve de gran utilidad para los productores, ya que pueden tomarla como referencia a la hora de decidir en qué fecha estrenar sus producciones.

Hoy en día, los nuevos soportes digitales que permiten obtener copias de las películas que hay en cartelera sin ninguna dificultad están suponiendo un problema adicional para la industria (Martí y Muñoz, 2001). Según expone Gil (2016), la "piratería casera" es la más extendida hoy; esto se debe a la facilidad que hay para duplicar las producciones desde las propias casas, lo cual la ha convertido en una actividad común. Además, la mayoría de los propietarios de las copias originales y los autores no reciben una compensación económica por estas reproducciones. Esta piratería está llevando al desarrollo de nuevas estrategias en el mercado cinematográfico. Según los datos aportados por el Observatorio de la Piratería en España, en 2015, el $87,48 \%$ de los contenidos descargados de la Web fueron ilegales. En una primera instancia se podría decir que la piratería es un enemigo de la cultura, pero si se analiza desde otra perspectiva se puede llegar a la conclusión de que los precios que tiene la cultura no son aptos para todos los públicos y precisamente esto es lo que está fomentando el aumento de la piratería.

Dado que las copias de los estrenos cinematográficos tardan cada vez menos en aparecer en la Internet de manera ilegal, la recaudación que las películas obtienen en la primera semana se está convirtiendo en la base para pronosticar su éxito. Por ello la fecha de estreno será la variable que se usará para la decisión estratégica en este trabajo, así como para analizar la evolución de los espectadores a lo largo del año.

La estacionalidad en la industria cinematográfica es un tema tratado con anterioridad en la literatura científica con numerosas aportaciones (Einav, 2007; Vila, Guzmán y Quintana, 2012; Zhang, Hou and Dong, 2017) que coinciden en destacar la importancia de este tema para la industria del cine.

El trabajo seguirá la siguiente estructura: en primer lugar se definirá la industria cinematográfica; posteriormente se describirá la metodología que se usará; a continuación, se analizará la estacionalidad existente en ambos países y los estrenos de las películas más taquilleras; finalmente se presentarán las conclusiones del trabajo, así como un estudio sobre los cambios en la distribución cinematográfica.

\section{La industria cinematográfica}

El sector cinematográfico es el que consta con más antigüedad dentro de los medios audiovisuales, siendo a la misma vez el que marca las tendencias de los demás medios (Martí y Muñoz, 2001). Según lo expuesto por González (2002) el cine puede entenderse como un bien cultural a través del cual se transmiten valores, conocimientos o experiencias y en su demanda intervienen multitud de factores, lo que hace necesario conocer de manera exhaustiva a los espectadores y sus preferencias en materia cinematográfica a fin de obtener una mayor recaudación.

La producción se refiere a la realización de un elemento material que puede ser una obra de un autor individual o de varios, el productor o productores son los encargados de obtener la financiación para llevar a cabo la película a la vez que se encargarán de conjugar los medios humanos y técnicos para la realización de la producción. La distribución pese a parecer el proceso más simple, ya que se encarga de comunicar las distribuidoras con las salas de cine donde se van a reproducir las películas, se ha convertido en el proceso más importante; se podría decir que es el sector más importante de los 3 puesto que será determinante 
para el desarrollo de la industria. Por último, el sector de la exhibición hace alusión a las formas en las que se hace llegar al público las distintas producciones; en donde el método más empleado son las salas de cine, aunque hoy existen un gran número de formas de comercializar las películas además de las tradicionales como pueden ser el DVD, la televisión o la Internet (con plataformas como, por ejemplo, Netflix) (Izquierdo, 2007).

La importancia del sector de distribución se debe a que este es el que se encarga de decidir factores que serán los que determinarán el éxito de las películas como pueden ser: la campaña publicitaria; la fecha del estreno; en qué salas y países se van a proyectar las producciones. Para Dadek (1962) en muchas ocasiones el distribuidor interviene en el diseño del producto para que este se adapte a sus características de distribución, esto suele darse en el inicio de la producción.

Acorde con el pensamiento de De Vany y Walls (1997), Terry, Butler y De'Armond (2003), Ainslie, Drèze y Zufryden (2005) dentro de la distribución será de suma importancia la fecha de estreno de las películas, siendo un factor muy relevante a la hora de establecer la estrategia competitiva. La fecha de estreno tendrá un gran componente estacional que será el que explique por qué unas salas recaudan más que otras y en qué meses es mayor esa recaudación; aunque no es el único factor que determinará el éxito puesto que el reparto, la presentación de la película en grandes festivales, los premios a los que opte, las ciudades y calidad de los estrenos que realice también serán factores que influyan en su éxito.

Según Augros (2000) existen 3 maneras fundamentales de distribuir las películas: (i) estreno exclusivo, las películas se estrenan en algunas ciudades y en el supuesto de que tengan éxito se podrían extender a más ciudades y salas; (ii) exhibición en plataforma, se realiza la proyección de las películas en un reducido número de salas en pocas ciudades y si tiene éxito se extenderán por el territorio. Esta manera de exhibición no usa una gran campaña publicitaria, más bien usa el boca-oído; (iii) estreno masivo, las películas se estrenan el mismo día en multitud de lugares y salas con una gran inversión en campaña publicitaria.

\section{La industria cinematográfica en España}

Debido a la gran globalización que se da hoy, se creó cierto debate sobre cómo se concentraban los medios de comunicación en la industria cinematográfica. Autores como Ellwood y Kroes (1994), Nowell-Smith y Ricci (1998), Segrave (1997) y Miller et al. (2005) piensan que el dominio de la industria estadounidense se debe al gran control de la distribución que ejerce. En esta industria existen factores que distorsionan la ley de la oferta y la demanda, pues desde el punto de vista de las grandes empresas norteamericanas el espectador es soberano; sin embargo desde el punto de vista europeo, el mayor éxito de la industria norteamericana no se debe tanto al gusto de los espectadores sino a que controlan el mercado de la distribución cinematográfica.

Para poder entender mejor cómo funciona la industria cinematográfica española es necesario tener una visión global de cómo es el mercado en Europa, concretamente en Europa Occidental. Pardo (2007) expone que en la industria europea el sector más débil es el de la distribución. Se ha producido una saturación del mercado dado al progresivo aumento de número de estrenos, lo que ha llevado a que se endurezca la competencia para las pequeñas distribuidoras europeas. El mercado está muy concentrado y las subsidiarias de las majors estadounidenses lo tienen bajo su control, aun así el $75 \%$ de las producciones distribuidas son de distribuidoras independientes europeas.

De acuerdo a datos aportados por el Observatorio Audiovisual Europeo -OAE(2015), los espectadores europeos aún son un poco recelosos en cuanto a ver películas de otros países del continente; tan solo el $24 \%$ de las producciones anuales europeas de 2015, llegaron a ser distribuidas en un país diferente al que se originaron.

En España las producciones han aumentado en los últimos 10 años, pasando de 150 en 2006 a 254 en 2016; de estas cifras corresponden a producciones íntegramente españolas 109 en 2006 y 214 en 2016, mientras que las coproducciones en 2006 ascendían a 41 y en 2016 a 40; tal como se puede observar en la figura 1 se aprecia que a partir de 2012 la industria 
cinematográfica empieza a evolucionar en gran medida después de prácticamente estancarse desde 2007, coincidiendo estos años con los mayores años de la crisis económica que ha estado aconteciendo en el país.

En cuanto a las coproducciones se puede observar también en la figura 1 como hay una tendencia al alza debido a las ventajas que proporcionan como, por ejemplo, tener acceso a mercados nuevos que tienen difícil acceso sin realizar este tipo de colaboraciones.

Se puede observar en la figura 2 que en la distribución cinematográfica de las salas españolas predominan aquellas producciones que son exportadas desde otros países ante la producción nacional; los datos en 2016 arrojan que 1277 largometrajes que fueron distribuidos en salas españolas eran de países extranjeros, esto frente a 451 largometrajes que sí que eran producciones españolas.

La evolución de la distribución de cine en nuestro país sigue una tendencia prácticamente con pequeñoscambios en cuantoalas producciones extranjeras y nacionales; pues en 2006, los datos observables en la figura 2 muestran que eran 1376 las producciones extrajeras frente a 372 españolas. Si bien es cierto que se puede observar un crecimiento considerable de la distribución de producciones españolas a lo largo de los 10 años de estudio con un incremento en casi 100 unidades, pasando de 372 (2006) a 451 (2016).

Estas cifras se deben en su mayoría a la respuesta del público, por lo que las distribuidoras deben idear una mejor manera de promocionar y publicitar las producciones españolas.

Tabla 1. Evolución de las productoras cinematográficas españolas (2006-2016)

\begin{tabular}{|c|c|c|c|c|c|c|c|c|c|c|c|}
\hline $\begin{array}{l}\text { Evolución de } \\
\text { productoras } \\
\text { españolas }\end{array}$ & 2006 & 2007 & 2008 & 2009 & 2010 & 2011 & 2012 & 2013 & 2014 & 2015 & 2016 \\
\hline 1 película & 138 & 167 & 179 & 191 & 198 & 218 & 212 & 226 & 242 & 298 & 299 \\
\hline Entre 2-4 películas & 41 & 37 & 34 & 36 & 44 & 37 & 32 & 37 & 31 & 40 & 51 \\
\hline Más de 4 películas & 4 & 9 & 4 & 7 & 7 & 4 & 2 & 4 & 3 & 5 & 4 \\
\hline Total & 183 & 213 & 217 & 234 & 249 & 259 & 246 & 267 & 276 & 343 & 354 \\
\hline
\end{tabular}




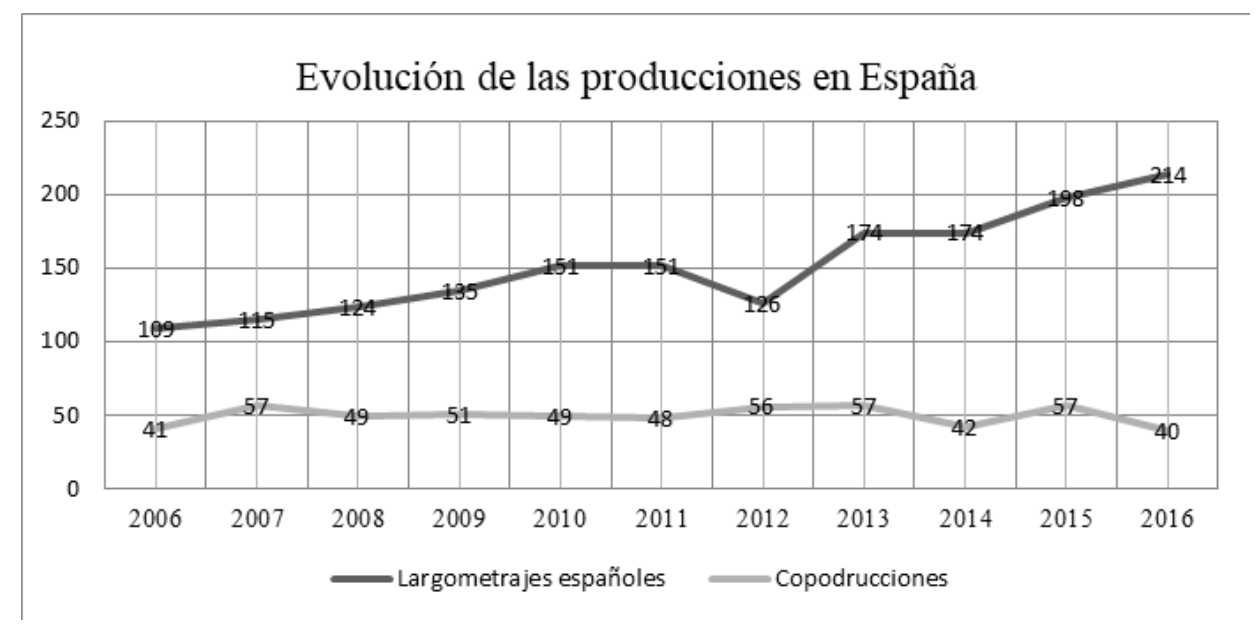

Figura 1. Evolución de la industria cinematográfica (2006-2016). Fuente: elaboración propia por parte de los autores.

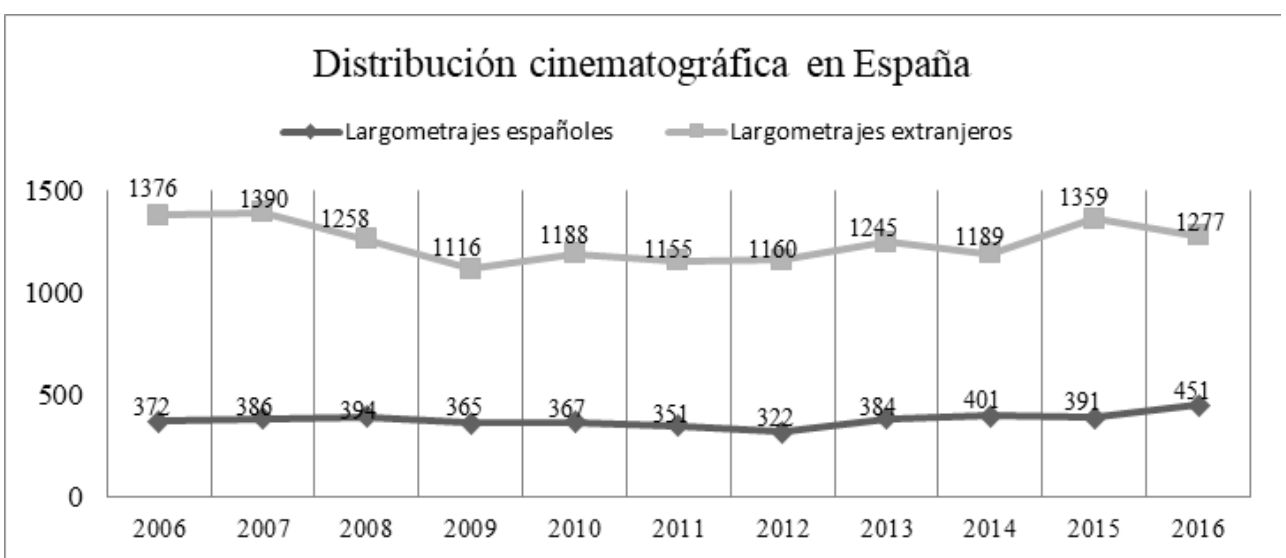

Figura 2. Evolución de la distribución cinematográfica en España (2006-2016). Fuente: elaboración propia por parte de los autores.

\section{La industria cinematográfica en Estados Unidos}

Como ya se mencionó la industria cinematográfica estadounidense apenas tiene rival tal como muestran datos del OAE donde acapara el $75 \%$ del mercado europeo, mientras el europeo en el estadounidense es alrededor del $5 \%$.

Para autores como Ellwood y Kroes (1994), Segrave (1997) y Stokes y Maltby (2004), el éxito de la industria estadounidense se debe en gran medida a que ha sabido transmitir sus valores y cultura al conseguir cambiar en la distribución los gustos de los consumidores y hacer que esos gustos sean iguales a los de ellos.

Miller et al. (2005), Acland (2003) y Pardo (2006) afirman que la industria cinematográfica mundial se caracteriza porque el talento se internacionalice, por utilizar localizaciones para los rodajes que están en diferentes zonas geográficas, la comercialización de las producciones por multiplataformas, estrenos mundiales y grandes campañas de marketing y distribución. Esto lo ha sabido adoptar muy bien la industria estadounidense, lo que ha hecho 
que se consolide como la principal industria cinematográfica.

La industria estadounidense ha conseguido aprovechar los nuevos soportes digitales con vistas a conseguir una mayor internacionalización de sus producciones, en este sentido Chalaby (2006) plantea: "toda gran corporación norteamericana ha fijado su vista en la expansión internacional y busca el modo de incrementar sus ingresos fuera de su territorio" (p. 33).

Hoy en día, pese a la supremacía estadounidense, se están dando ciertas cooperaciones con la industria europea y se están dejando atrás antiguas rivalidades. Estas cooperaciones se pueden observar en ejemplos como que las grandes productoras norteamericanas no solo utilizan sus filiales europeas como simples distribuidoras sino que financian en parte las producciones de estas. También se puede observar el intercambio de talento, no solo con actores y actrices sino con productores y directores que cruzan el Atlántico en ambas direcciones (Pardo, 2007).

Desde el principio el cine en Estados Unidos fue entendido como una forma de entretenimiento, a diferencia de Europa que fue visto como una obra de arte o modo de propaganda política. Estados Unidos instauró un modelo industrial de producción a gran escala en un modelo económico basado en el libre comercio donde prevalece la inversión privada. Esto, unido a sus grandes estrategias de marketing y distribución global ha hecho que la industria estadounidense esté en su posición de supremacía (Pardo, 2010).

Acorde a los datos aportados por la Asociación Cinematográfica de Estados Unidos (tabla 3), la evolución de la industria cinematográfica ha aumentado al pasar de 611 producciones en 2007 a 718 en 2016. Los datos muestran las producciones realizadas tanto por los miembros de esta como por aquellas productoras que son subsidiarias (nacionales e internacionales) de las productoras miembros de la asociación, a la vez que muestra los datos de aquellas productoras que trabajan de manera independiente. Dentro de las productoras miembros de la asociación se encuentran grandes nombres a nivel mundial como son: Walt Disney Motion Pictures; Paramount Pictures Corporation; Sony Pictures Entertainment; Twentieth Century
Fox Film Corporation; Universal City Studios LLC y Warner Bros. Entertainment.

Las producciones totales en Estados Unidos se han mantenido a un nivel constante en los últimos cinco años (tabla 4) donde se han clasificado las películas según las productoras miembros y no miembros de la asociación, así como aquellas que tienen un presupuesto mayor a 1 millón de dólares y aquellas que cuentan con un presupuesto menor. Se aprecia que desde 2012, las productoras estadounidenses han destinado un mayor presupuesto para sus producciones dado que en ese año las películas que contaban con un presupuesto mayor a 1 millón de dólares eran 476 y en 2016 el total de películas que superaban este presupuesto fue de 510. Este aumento ha sido gradual, pues es posible observar como a lo largo de los años las productoras estadounidenses han ido destinando más presupuesto en la elaboración de sus producciones.

Como se observa en la figura 3 la distribución de las producciones estadounidenses encuentra un gran apoyo en la internacionalización, pues la mayoría de los ingresos producidos en los últimos 5 años (en torno al $70 \%$ ) se deben a la recaudación en países que no son el país productor. Además resulta relevante que la tendencia en la distribución de películas, tanto dentro de las fronteras estadounidenses como fuera de las mismas, es prácticamente lineal durante los últimos años de los que constan datos. Asimismo, es apreciable un pequeño repunte de la distribución tanto nacional como internacional en los últimos 2 años.

\section{Metodología}

Con la finalidad de poder observar las variaciones estacionales que se dan en la industria cinematográfica he obtenido datos del Ministerio de Cultura sobre la variación de la taquilla española en cuanto a lo referente a los espectadores de películas españolas y norteamericanas. La serie corresponde con la variación de la taquilla entre 2006-2016, atañendo con los últimos años de los que constan datos. La serie empleada para realizar el modelo se trata de la variación trimestral 
del número de espectadores de largometrajes españoles y largometrajes extranjeros.

A través de los datos proporcionados por el Instituto de Cinematografía y de las Artes Audiovisuales -ICAA- he realizado una base de datos donde constan el número de espectadores que han acudido a las salas desde 2006 a 2016 para su posterior tratamiento con el programa EViews. Al observar la evolución de los espectadores se puede conocer del mismo modo la evolución de la demanda en el período de estudio. Así, al analizar estos datos se pude contemplar en qué períodos del año acuden más espectadores a las salas cinematográficas.

Los datos conforman una serie temporal, es decir, se trata de observaciones de una variable determinada que se suceden a lo largo del tiempo (Uriel y Muñiz, 1993). Principalmente, lo que se trata de realizar con el estudio de una serie temporal es comprobar cómo se desarrolla una variable durante el período de tiempo que se esté estudiando; en este caso será analizar cómo se comportan los espectadores de cine a lo largo del año, así como saber si este comportamiento es el mismo a lo largo de los años o son comportamientos esporádicos.

Como afirman Box, Jenkins y Reinsel (1994), Brockwell y Davis (1991) y Harvey (1993), el estudio de una serie temporal es el tratamiento ideal para analizar datos que se encuentran correlacionados. Las series temporales poseen una gran capacidad predictiva que resulta muy útil para las grandes empresas cinematográficas, ya que les permite anticiparse a como se comportará su demanda con base en el comportamiento que esta ha tenido en el pasado.

En las series temporales suele darse un compartimiento estacional que podría definirse como las veces en las que una variable se comporta del mismo modo en los mismos meses o períodos del año, esto es lo que se denomina estacionalidad. Debido a que en la serie se presenta un comportamiento repetitivo de carácter anual, será necesario eliminar y analizar estas variaciones con el fin de poder realizar un análisis más adecuado. Para poder desestacionalizar la serie, el método que se lleva a cabo es el de la razón de la media móvil.
Caparrós y Marcenaro (2016) sostienen que mediante este método se obtienen los coeficientes que resumen en un solo valor la estacionalidad para cada período. Así, se podrá obtener una serie desestacionalizada.

El programa EViews permite desestacionalizar la variable, utilizando el método de la razón a la media móvil, esto permitirá definir la manera para tratar la variable. Los métodos que se pueden utilizar son los de la hipótesis multiplicativa o la hipótesis aditiva. Suponiendo que las variaciones de la serie son constantes en los mismos trimestres de cada año, se puede obtener su cuantificación en índices si se ha optado por la opción de la hipótesis multiplicativa tal como es el caso de este trabajo. Es fácil reconocer que se ha usado la opción multiplicativa porque los valores de los índices oscilan en torno a 1 (tablas 2 y 3 ).

Tabla 2. Índices de largometrajes españoles

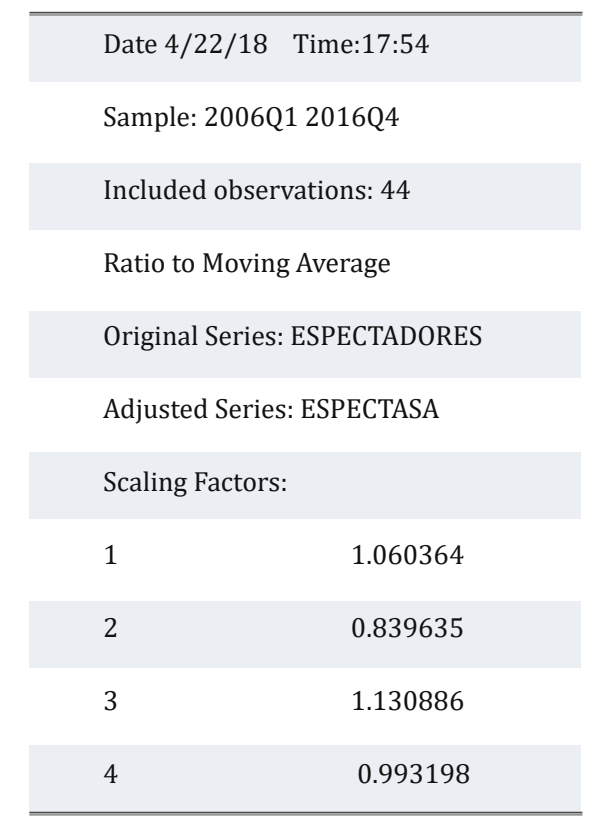

Fuente: elaboración propia por parte de los autores. 
Tabla 3. Índices de largometrajes extranjeros

Date 4/22/18 Time:18:15

Sample: 2006Q1 2016Q4

Included observations: 44

Ratio to Moving Average

Original Series: ESPECTADORES

Adjusted Series: ESPECTASAEX

Scaling Factors:

1

0.877021

2

0.804061

3

0.815014

Fuente: elaboración propia por parte de los autores.

Se ha desestacionalizado la variable para que los datos se ajusten de la mejor manera posible a la realidad, obteniendo una nueva serie en la que se ha eliminado el componente estacional. De ahí se obtendrán 4 series: una de ellas será el componente error; otra de ellas será la serie corregida estacionalmente; los componentes de tendencia-ciclo suavizados, esto quiere decir que la variable fluctúa en torno a una constante y no presenta tendencia ni componente cíclico; por último, los factores de corrección estacional que mostrarán el efecto que tendrá cada período en la variable.

Para poder lograr el objetivo del trabajo se analizará la base de datos trimestrales elaborada previamente, en dondehay datos correspondientes a espectadores de largometrajes españoles y estadounidenses. La elección de este último país como referente, para realizar la comparativa, se debe a la gran hegemonía que tiene en la industria cinematográfica mundial. A modo de completar el estudio de demanda se realizará una comparativa de las 10 películas más taquilleras en España y en Estados Unidos en 2017.

\section{Análisis de la estacionalidad de la taquilla en España}

Para poder realizar el estudio de la estacionalidad se ha procedido a recopilar información del Ministerio de Cultura sobre la variación de los espectadores en las salas españolas en los diferentes trimestres del período de estudio. En la base de datos se encuentran agrupados por trimestre los espectadores que acudieron a ver películas españolas y los que fueron a ver películas estadounidenses.

La variación de las alturas desde los picos hacia los valles va aumentando mientras que el valor medio va creciendo, es decir que el componente cíclico va aumentando de manera más o menos regular a lo largo de los años.

En la figura 3 se puede observar como varían en gran medida a lo largo del año el número de espectadores que acuden a las diferentes salas aver tanto películas españolas como estadounidenses. Se puede observar que hay estacionalidad en la serie, pues es fácilmente reconocible como en los mismos períodos anuales se dan los picos más elevados de asistencia al cine tanto para películas españolas como estadounidenses (figura 3). Si bien es cierto que los períodos de mayor afluencia son diferentes respecto a la nacionalidad del largometraje. 


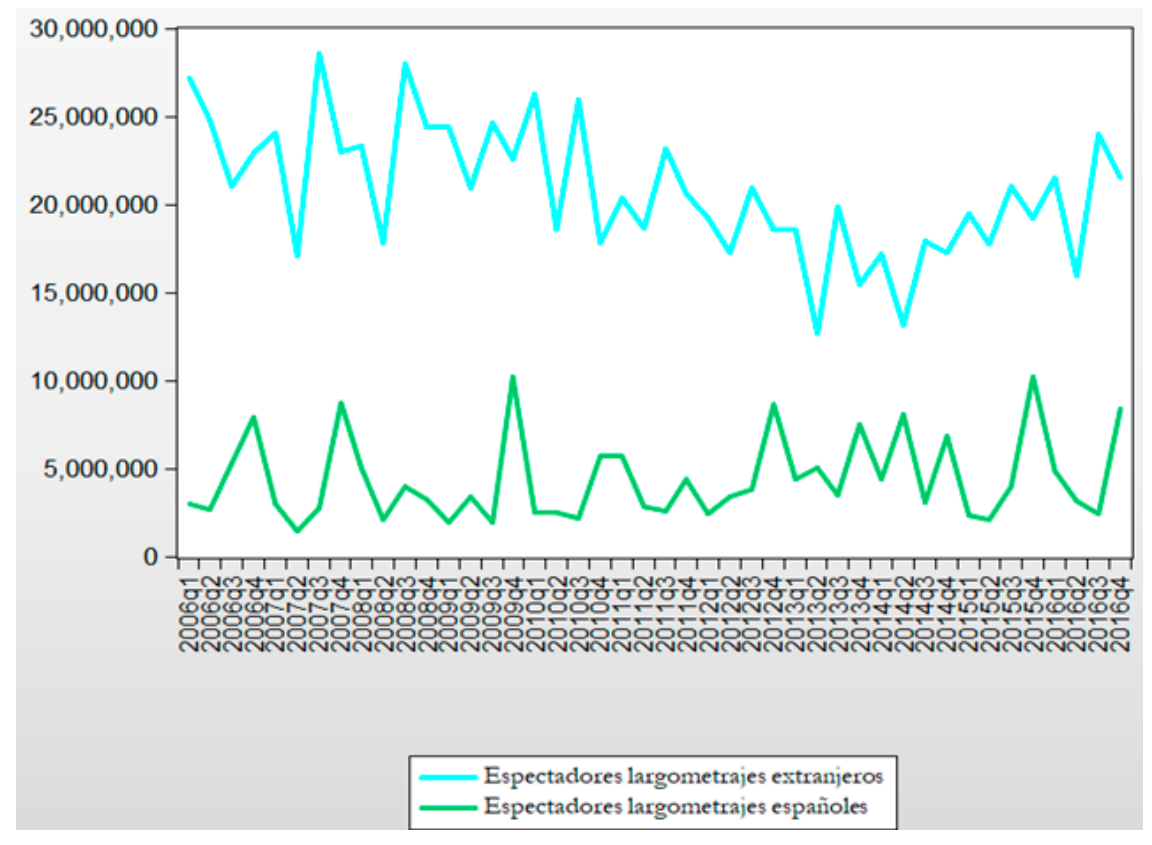

Figura 3. Evolución de los espectadores (2006-2016). Fuente: elaboración propia por parte del autor.

Para realizar un análisis más detallado de la estacionalidad de las películas españolas y estadounidenses se va a proceder a analizarlas por separado.

Por un lado se va a analizar la estacionalidad que se da en las películas estadounidenses (figura 4) cuya mayor afluencia de público se da en los meses correspondientes al segundo y tercer trimestre del año, coincidiendo con el período vacacional de los clientes. Se puede observar que la serie tiene una clara tendencia anual, ya que los picos y los valles se repiten prácticamente en los mismos períodos cada año. También es apreciable la estacionalidad que existe en cuanto a los meses del año en los que más público acude a las salas cinematográficas, pues los meses donde los clientes pueden hacer mayor disfrute de su tiempo de ocio y período vacacional coinciden ciertamente con los meses de verano, teniendo un leve repunte a final de año por las festividades como la Navidad.

Por otro se realiza un análisis de la estacionalidad en las películas españolas (figura 5), en donde la mayor afluencia de público a las salas cinematográficas corresponde con los períodos iniciales y finales del año; sin embargo esta tendencia no se da durante todo el período sino que se da sobre todo a partir de 2009, coincidiendo con los primeros años de la crisis económica que ha acontecido en España desde 2008 y que ha afectado a todos los sectores por igual. Se puede observar, además, que la tendencia de la serie también es anual dado que los picos y valles se dan en los mismos períodos anuales tal como ocurría en el caso de las producciones estadounidenses. La estacionalidad de las producciones españolas es diferente a la de las producciones estadounidenses puesto que mientras estas últimas suelen tener más afluencia en períodos vacacionales de los clientes, en las españolas esto no ocurre; su mayor afluencia se concentra en los últimos meses del año, teniendo su mayor repunte en el mes de diciembre, ya que muchas personas aprovechan las festividades de Navidad para emplear mayor tiempo en su ocio.

En ambas series es fácilmente observable, a través de la figura 3 , como la afluencia de público a las salas donde se proyectan las diferentes producciones ha disminuido de manera considerable a pesar de que se observa un pequeño repunte desde 2016. El hecho que ha podido 
impulsar que los clientes acudan menos a los cines puede estar ocasionado por el gran número de plataformas que ofertan las producciones de manera gratuita o mediante una cuota mensual al poco tiempo de que se haya realizado su estreno. Estas cuotas ofrecen un precio por el cual el cliente puede no solo ver esa producción sino una gran variedad de producciones de todo el mundo (tanto películas como series) a un precio que no es mucho mayor al precio de las entradas de cine. Los espectadores parecen estar dispuestos a pagar un poco más, si tienen una mayor oferta y la comodidad de estar en su casa.

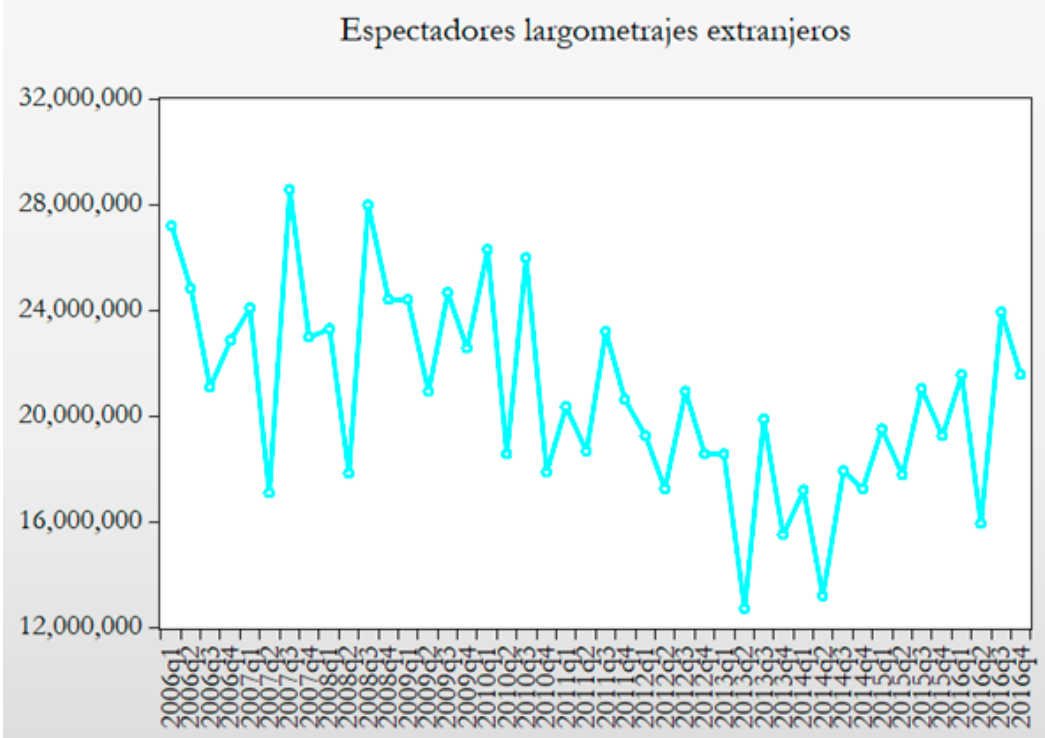

Figura 4. Evolución de espectadores extranjeros (2006-2016). Fuente: elaboración propia por parte del autor.

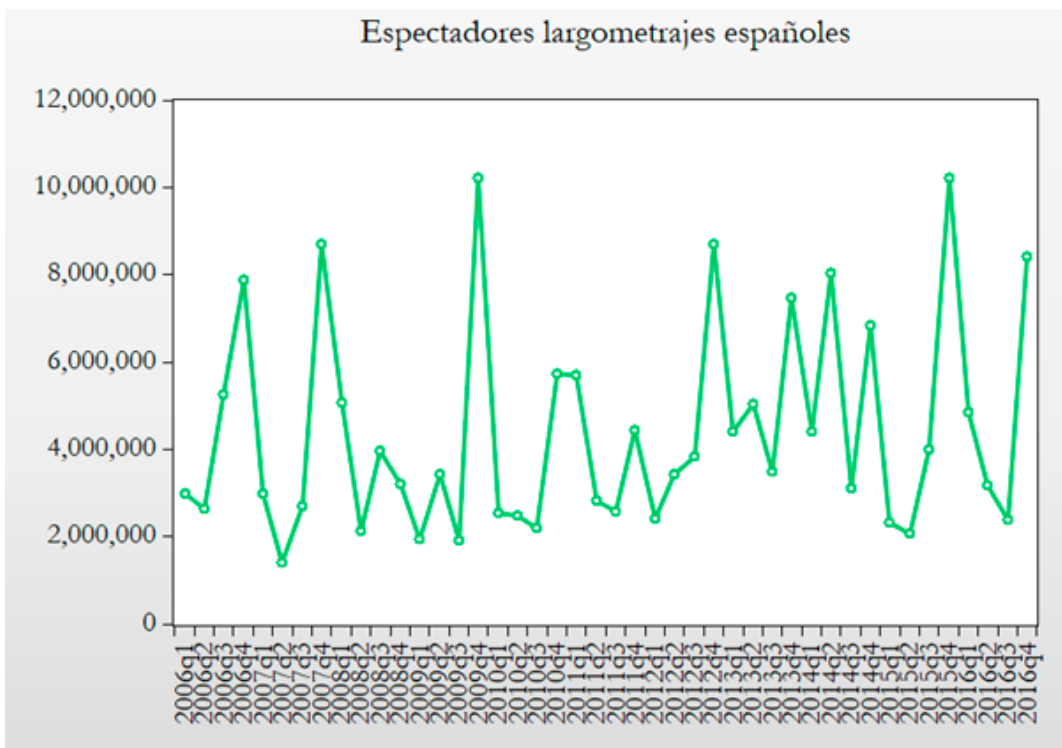

Figura 5. Evolución de espectadores españoles (2006-2016). Fuente: elaboración propia por parte del autor. 


\section{La digitalización y como está cambiando la distribución de la industria cinematográfica}

Tradicionalmente la industria cinematográfica ha estado dividida en 3 procesos, a saber: producción, distribución y exhibición. A través de observar la evaluación temporal de estos procesos se puede llegar a ver una nueva tendencia tecnológica, la digitalización. Sin embargo solo se puede hablar de digitalización en los procesos, pues las características que posee la industria cinematográfica hacen que sea más difícil la adaptación total de la digitalización a diferencia de otros medios audiovisuales como la televisión (Marzal y Casero, 2017).

Rubio (2006) expone que la digitalización cinematográfica comenzó con los tratamientos de las imágenes en posproducción, este nuevo tratamiento de las imágenes supuso una mejora creativa y el abaratamiento de los costes sobre todo en el proceso de edición. Como asegura Izquierdo (2009), la consolidación de la sala digital ha sido un proceso bastante lento dado que lo segundo que se digitalizó fue la exhibición de las producciones en las salas. Por último, la distribución es la última fase en incorporar la digitalización a su tecnología.

Desde sus inicios el cine ha ido cambiando de manera sustancial, ha pasado por numerosos cambios que han supuesto un punto de inflexión. El último de ellos ha sido la digitalización. Fue así como se pasó de meras imágenes en movimiento a ser un gran espectáculo donde las bandas sonoras pasaron a tomar gran parte del protagonismo. Del mismo modo el color fue otras de las grandes revoluciones, pero lo que ha llevado a la digitalización ha sido la necesidad de poder competir frente a la televisión y poder así conseguir modernizar las salas cinematográficas (Izquierdo, 2010).

Sychowski (2010) afirma que los cambios en las tecnologías y la necesidad de adaptarse a los nuevos tiempos hace que se compliquen los procesos industriales, esto ha llevado a que aparezcan nuevos agentes que ofrezcan soluciones de actualización y gestión, lo que hace que la estructura de la industria se aún más compleja.
La distribución es el sector menos vinculado a la tecnología, básicamente lo que esta realiza es la selección de contenido y su puesta a la venta en los puntos de exhibición. Lo más difícil para las distribuidoras es valorar la película, el número de copias a poner en venta, seleccionar en cuántos mercados se va a emitir la producción y la negociación con los dueños de las salas de exhibición, las cadenas de televisión y recientemente también con las plataformas de Internet (Izquierdo, 2010).

\begin{abstract}
Según lo aportado por Izquierdo (2010), la distribución digital cinematográfica se fundamenta en transportar archivos transformados con contenido audiovisual. Normalmente este material es distribuido mediante una copia digital almacenada en un DVD de gran capacidad, cuando el DVD llega a las salas donde va a ser distribuido es almacenado en un servidor en el que se encontrará hasta que llegue la fecha en la que debe ser exhibido. Para evitar un uso fraudulento del contenido de la película, los archivos son encriptados.
\end{abstract}

Lo que lleva a que las majors norteamericanas consigan tener gran control de este mercado se debe a la estandarización de sus contenidos, siendo estos sometidos al mismo tratamiento sin importar el mercado en el que se encuentren.

La realización de los archivos digitales, que se denominan master digital, ocurre en varias fases. En una primera instancia se le incluye un código de seguridad, a la vez que recibe los tratamientos necesarios para que el archivo pueda ser enviado de manera digital. A continuación, la copia es distribuida a las salas. La siguiente fase es cuando se realiza la emisión de una señal vía Internet para poder activar la emisión del contenido a las salas; esta fase es crítica porque se pone a prueba la fiabilidad del encriptado y si va a funcionar acorde se ha diseñado. Una vez el archivo ha llegado a las distribuidoras, estas almacenan el contenido en grandes servidores con una inmensa capacidad de almacenamiento de memoria; esto supone una ventaja frente a la era analógica puesto que estos servidores permiten un gran ahorro en espacio y coste de almacenamiento respecto al método de almacenar de la era anterior en el que se tenían grandes almacenes con copias físicas de las diferentes películas a proyectar (Izquierdo, 2010). 
Écija (2000) señala que la Internet se ha convertido en un gran aliado para la distribución digital de los contenidos cinematográficos. No obstante, el consumo de cine fuera de las salas no es algo nuevo que haya ocurrido con la aparición de la Internet sino que siempre ha estado relacionado con los hábitos de la industria y la aparición de nuevas tecnologías. Por ello las distribuidoras vieron una gran oportunidad de seguir comercializando sus producciones en la televisión con los DVD o más recientemente con la Internet, una vez que hubiesen rentabilizado sus películas en las taquillas.

No obstante, según Papies y Clement (2008), las grandes compañías norteamericanas tardaron demasiado tiempo en darse cuenta de que Internet produciría una mejora en la comercialización de sus producciones; esto, debido al miedo que tenían de perder poder de comercialización.

Fue así, mediante la decisión de las grandes distribuidoras de comercializar sus producciones a través de la Web, cuando surgieron acuerdos con Netflix. Como ya se explicó en el acápite anterior, el éxito de Netflix y demás plataformas se debe a saber adaptarse a la demanda por medio de la oferta de un gran catálogo al que se puede acceder pagando una cuota mensual sin límite para visualizar producciones a lo largo de ese mes.

Como aporta Izquierdo (2012), estas acciones no son solo beneficiosas para los productores y consumidores sino que estas plataformas se ven beneficiadas a la vez porque pueden acordar distribuir de manera exclusiva ciertas producciones.

La Internet ha supuesto un gran cambio en cuanto a la visión de los espectadores, ya que tienen la oportunidad de acceder a contenido personalizado bajo su propia demanda y no solo adaptarse a la oferta de las distribuidoras. Todo ello ha sido impulsado por la gran oferta multicanal a la que los espectadores tienen acceso, pues las plataformas de las distribuidoras permiten comprar de manera digital una película; esto, a diferencia de los tiempos pasados donde la única opción que tenían los clientes era realizar la compra de los contenidos en formato DVD (Izquierdo, 2012).
Se puede concluir que la digitalización ha supuesto un gran cambio en la industria cinematográfica, siendo una gran revolución en cuanto a la manera de distribuir las producciones tanto en las salas donde se realizará su exhibición como su posterior comercialización.

\section{Análisis comparativo de las fechas de estreno de las producciones españolas y estadounidenses}

Con objeto de poder analizar de manera comparativa los meses donde las distribuidoras deciden realizar el estreno de sus producciones se han seleccionado aquellas películas que consiguieron ser las más taquilleras en España en el período 2006-2016. En concreto, se han seleccionado las 10 películas españolas más taquilleras y las 10 películas estadounidenses más taquilleras durante ese período.

La mayoría de las películas más taquilleras de la taquilla española en los últimos 10 años se estrenaron en el cuarto trimestre del año, así 5 de los estrenos más taquilleros fueron entre los meses de octubre y diciembre de sus respectivos años; seguidamente es el tercer trimestre en el que más películas taquilleras han tenido lugar con un total de 3 estrenos, comprendidos en los meses de agosto y septiembre; por último, 2 de las películas tuvieron su estreno en marzo en el segundo trimestre del año.

La mayoría de las películas estadounidenses que más éxito tuvieron en taquilla en los últimos 10 años se estrenaron entre el segundo y tercer trimestre de sus respectivos años. Concretamente 3 estrenos tuvieron lugar en el mes de mayo, coincidiendo con el segundo trimestre; mientras en el tercer trimestre se pueden apreciar que fueron 3 los estrenos acontecidos repartidos entre los meses de julio y agosto; en el cuarto trimestre también se dan 3 películas estrenadas entre los meses de noviembre y diciembre y finalmente se encuentra un único estreno en el mes de febrero. 
Los estrenos de las películas españolas están más concentrados que los de las estadounidenses, pues como se ha descrito previamente las películas españolas suelen estrenarse especialmente en los últimos meses del año mientras que las norteamericanas tienen una cuota de estreno bastante balanceada a lo largo del año. Además, los estrenos norteamericanos suelen coincidir con períodos donde el público dispone de más tiempo libre ya sea porque son meses donde disponen de períodos vacacionales o porque son meses donde (por razones climatológicas, sociales entre otras) las personas tienden a pasar más tiempo fuera de sus casas disfrutando de la oferta de ocio que se les brinda incluidas las salas cinematográficas. Entretanto los estrenos españoles suelen tener lugar en mayor medida en los meses de invierno, mayormente en diciembre, coincidiendo con el período de la festividad de Navidad.

En los últimos años en España (en los meses de mayo y octubre) tiene lugar la llamada Fiesta del Cine en la que (normalmente la primera semana de los mencionados meses) las entradas alcanzan un precio de 3,90€ (un 43,82\% menos que su precio habitual $(8,90 €))$, por lo que muchas de las distribuidoras optan por lanzar sus películas poco antes de estas fechas para que así la afluencia de público sea mayor. Como se puede observar en las siguientes figuras las películas estadounidenses se estrenaron en la primera de las 2 ediciones anuales, mientras las españolas en la segunda de estas. Esto podría suponer, en cierto grado, un factor que definiría la diferencia existente entre las producciones de ambos países.

Los mejores años para las películas españolas, en lo referente al mayor número de películas españolas que consiguieron estar dentro de las 10 más taquilleras, fueron 2012 y 2015. Mientras que los años en los que ninguna producción consiguió estar en esta posición fueron 2008, 2009, 2010 y 2013.

Las películas que consiguieron estar en el primer puesto de la taquilla española fueron 6: $E l$ orfanato (2007); Torrente 4: Lethal crisis (2011); Lo imposible (2012); Ocho apellidos vascos (2014); Ocho apellidos catalanes (2015) y Un monstruo viene a verme (2016).

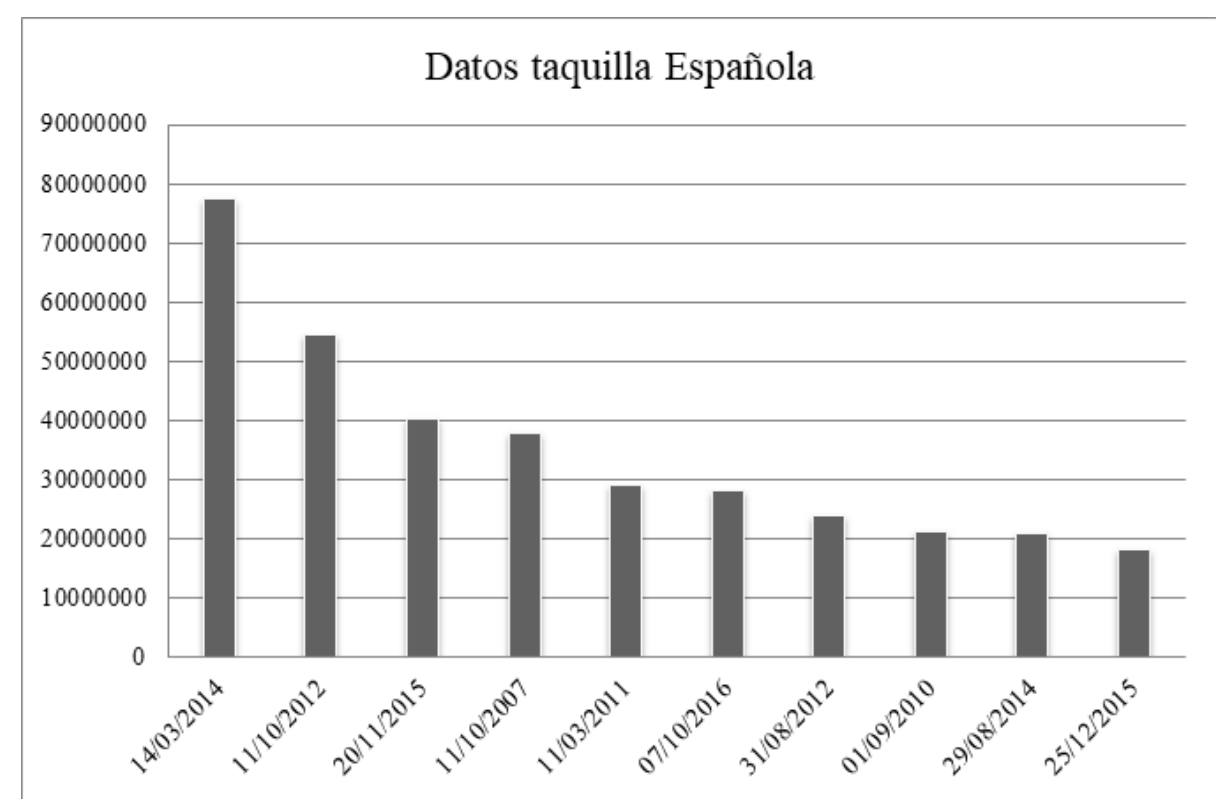

Figura 6. Las diez películas españolas más taquilleras (2006-2016). Fuente: elaboración propia por parte del autor. 


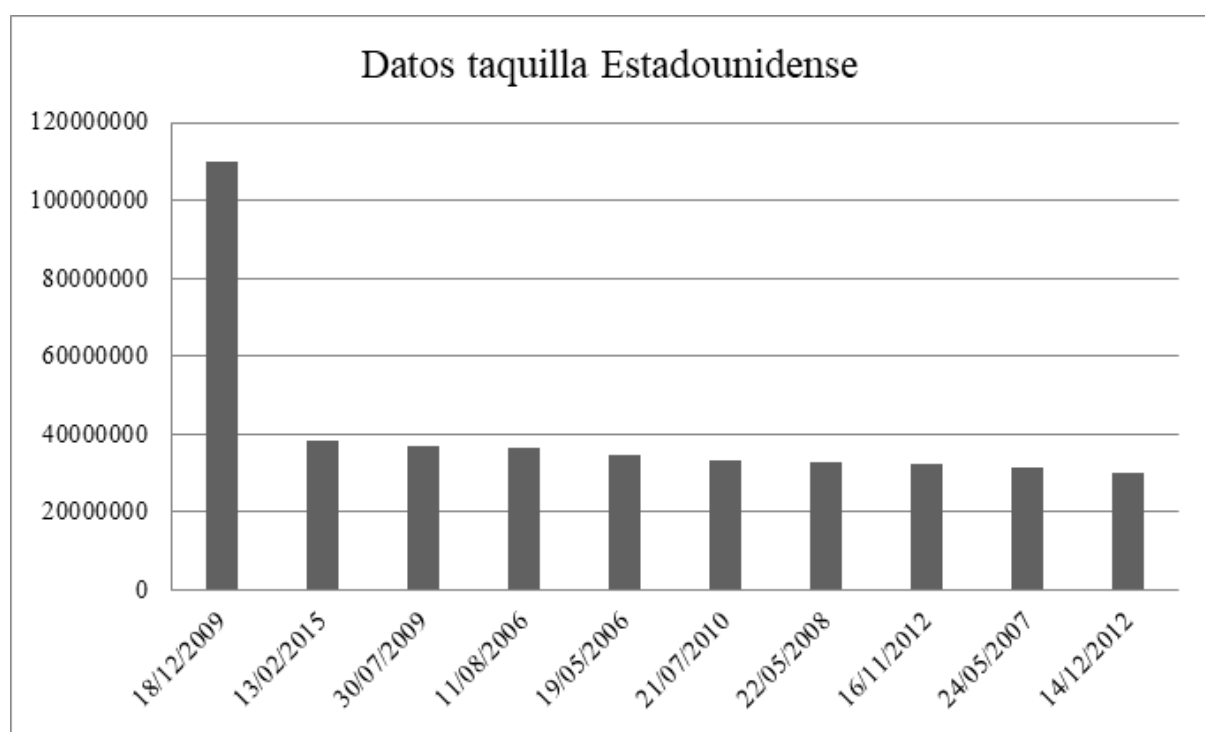

Figura 7. Las diez películas estadounidenses más taquilleras (2006-2016). Fuente: elaboración propia por parte del autor.

\section{Análisis comparativo del número de espectadores en las películas más taquilleras españolas y estadounidenses}

A continuación, se va a realizar un análisis comparando la afluencia de público a las diferentes películas más taquilleras tanto de España como en Estados Unidos. Para iniciar este estudio se han obtenido los datos referentes al número de espectadores de las películas que en el epígrafe anterior resultaron ser las 10 más taquilleras en los últimos 10 años.

Los meses preferidos por el público español son los meses comprendidos entre agosto $\mathrm{y}$ diciembre, dentro de las 10 películas 8 de las que más afluencia de público tuvieron se encuentran entre estos meses; no obstante, la película que más afluencia de público tuvo fue estrenada en marzo.

Respecto a la afluencia de público para ver películas estadounidenses los meses elegidos para realizar su asistencia a las salas cinematográficas son los meses comprendidos entre mayo y agosto, coincidiendo con el segundo y tercer semestre del año. Aun así, la película que más espectadores recibió en su estreno tuvo lugar en el mes de diciembre.

Una vez más, se puede comprobar la diferencia entre un país y otro en cuanto a la elección tanto de las fechas de estreno como a la preferencia del público para acudir a ver las producciones. Por consiguiente, las producciones españolas tienen preferencia a ser estrenadas en el último cuatrimestre del año; esto puede deberse a que en estos meses es cuando mejor respuesta reciben por parte del público. En el caso estadounidense las preferencias son hacía los meses de primaveraverano (es decir, el segundo y tercer trimestre del año), ya que es cuando mejor respuesta reciben estas producciones por parte del público español. Sin embargo la película que más espectadores recibió, tanto en las producciones españolas como norteamericanas, fue en fechas que no coincidían con aquellas en las que suelen estrenarse las películas en ambos países.

La película más taquillera en España entre 2006-2016, en lo que respecta al número de espectadores, fue Ocho apellidos vascos (una producción española estrenada el 14 de marzo de 2014); mientras que la película más taquillera en Estados Unidos fue Avatar, una producción que vio la luz el 18 de diciembre de 2009. 
De igual manera se pude observar una notable diferencia entre la cantidad de espectadores que acuden a visualizar películas españolas y estadounidenses; mientras que el número de espectadores total de la película que ocupa el primer puesto en ambos países es similar, a medida que se va bajando en el ranking se puede ser testigo de la citada diferencia.

Podría decirse que la taquilla española se caracteriza por películas que tienen un número de espectadores que se mantiene en torno a un mismo número, salvo ciertas producciones que sobresalen con un mayor número de espectadores por diferentes motivos ya sea por su publicidad, por el renombre del director, gustos de los consumidores u otros. Por otro lado, las películas estadounidenses parecen contar con un público más fiel que el de las películas españolas; pues se puede apreciar que las diferencias en la afluencia de público son menores y más graduales que las de las películas españolas, aunque como ocurre en el caso español hay ciertas producciones que sobresalen de las demás.

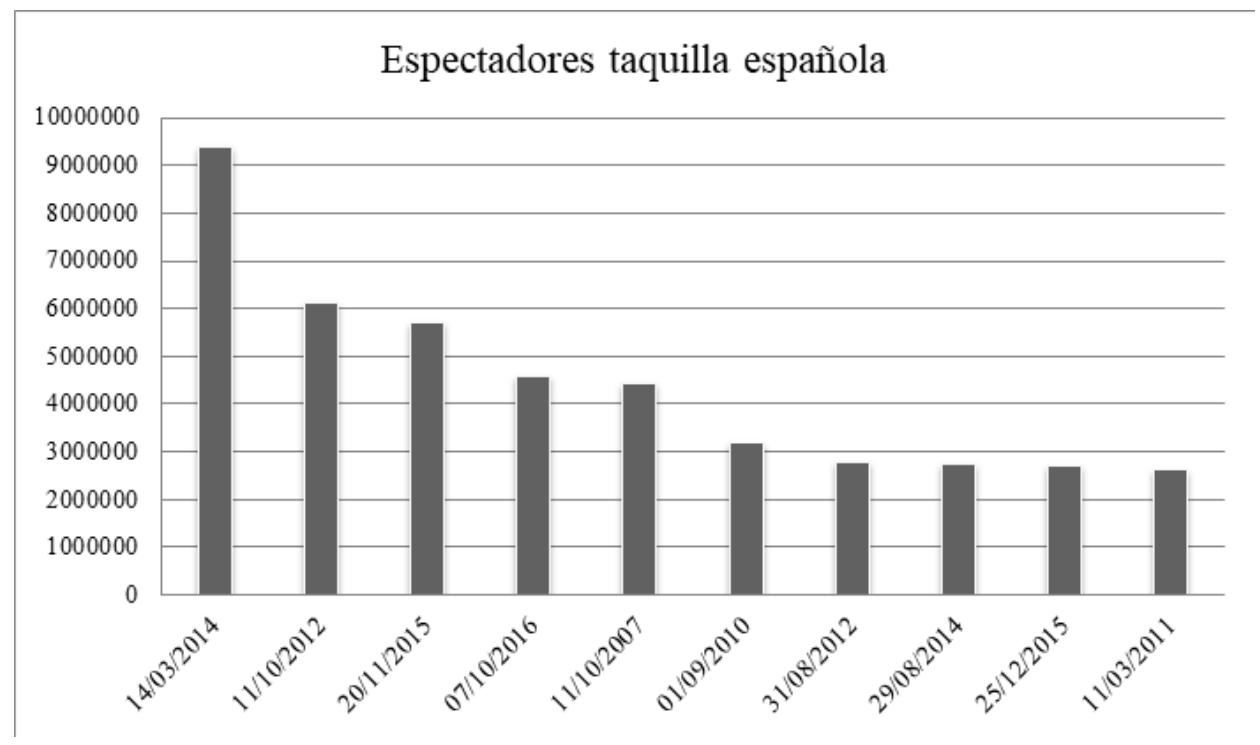

Figura 8. Espectadores de las diez películas españolas más taquilleras (2006-2016).

Fuente: elaboración propia por parte del autor.

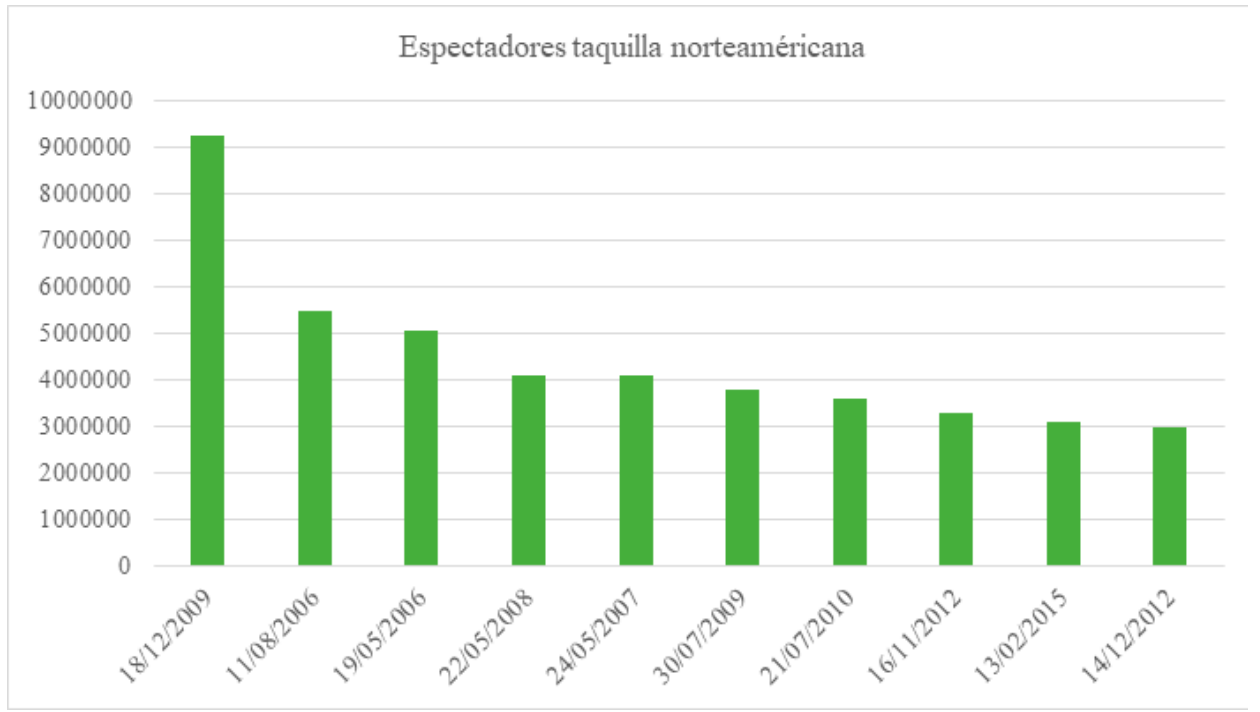

Figura 9. Espectadores de las diez películas estadounidenses más taquilleras (2006-2016). Fuente: elaboración propia por parte del autor. 
Tabla 4. Espectadores de las diez películas españolas más taquilleras

\begin{tabular}{lc}
\hline \hline Nombre de películas & Espectadores \\
\hline \hline Ocho apellidos vascos & 9397647 \\
\hline Lo imposible & 6129025 \\
\hline Ocho apellidos catalanes & 5689501 \\
\hline Un monstruo viene a verme & 4584941 \\
\hline El orfanato & 4420636 \\
\hline Alatriste & 3182186 \\
\hline Las aventuras de Tadeo Jones & 2761627 \\
\hline El niño & 2757638 \\
\hline Palmeras en la nieve & 2704805 \\
\hline Torrente 4: Lethal crisis & 2632922 \\
\hline \hline
\end{tabular}

Fuente: elaboración propia por parte de los autores.

Tabla 5. Espectadores de las diez películas estadounidenses más taquilleras (2006-2016)

\begin{tabular}{lc}
\hline \hline Nombre de películas & Espectadores \\
\hline \hline Avatar & 9249850 \\
\hline $\begin{array}{l}\text { Piratas del Caribe 2: el cofre del hom- } \\
\text { bre muerto }\end{array}$ & 5495970 \\
\hline El código Da Vinci & 5071930 \\
\hline $\begin{array}{l}\text { Indiana Jones y el reino de la calavera } \\
\text { de cristal }\end{array}$ & 4107584 \\
\hline $\begin{array}{l}\text { Piratas del Caribe: en el fin del } \\
\text { mundo }\end{array}$ & 4107538 \\
\hline Up & 3790756 \\
\hline Toy Story 3 & 3624912 \\
\hline La saga crepúsculo: amanecer & 3287795 \\
\hline Cincuenta sombras de Grey & 3109150 \\
\hline El hobbit: un viaje inesperado & 3004494 \\
\hline
\end{tabular}

Fuente: elaboración propia por parte de los autores.

\section{La crisis y su impacto en la industria cinematográfica}

Para Simón (2014) desde 2008 hasta 2013 no hubo ningún aumento considerable de las producciones realizadas en un año, pero esto no indica que la crisis no se haya notado en la industria cinematográfica; el sistema de subvenciones que el Estado proporciona a la industria ha cambiado, generando que el presupuesto para realizar películas sea muy escaso, lo que ha llevado a la producción de películas de bajo presupuesto y por lo tanto de baja calidad.

Parte de que la crisis haya afectado al cine español se debe a que este no ha sabido adaptarse de manera proactiva a los cambios acontecidos por la era digital, pues ha sido una de las últimas industrias cinematográficas en realizar los cambios de las producciones analógicas a producciones digitales (Pérez, 2013).

Díaz-González (2016) expone que, desde 2008, se atribuye que la crisis ha afectado a la industria de igual manera que lo ha hecho con otras industrias. Pero la realidad es que el Estado debería estar realizando cambios para fomentar y ayudar a contrarrestar los efectos negativos que este período ha podido causar en la industria cinematográfica.

La industria española se fundamente en producciones débiles si las comparamos con las producciones estadounidenses, excepto éxitos puntuales como puede ser Ocho apellidos vascos.

Las producciones españolas no resultan rentables, pues su financiación suele realizarse mediante crowdfunding; esto quiere decir que la producción está financiada tanto por subvenciones que otorga el Estado como por acuerdos con grandes productoras que invierten su dinero en estas películas (Simón, 2014).

Según Pérez (2013), las películas españolas no son rentables. La escasa rentabilidad que aportan las películas españolas, unidas a la crisis donde las subvenciones para la industria cinematográfica son cada vez menores, ha llevado a que la industria española esté pasando por un período que se hace cada vez más acuciado; todo promovido no solo por la crisis económica del país, sino también por 
la piratería. La crisis económica ha perjudicado al cine en la medida en que no solo se invierte menos dinero en realizar las películas sino que los precios de las entradas son mayores, así como el poder adquisitivo de los espectadores se ha visto seriamente afectado.

\section{Conclusiones y limitaciones}

La finalidad de este trabajo ha sido comprobar si la estacionalidad presente en la industria cinematográfica española es la misma que la de las películas extranjeras, concretamente la industria cinematográfica estadounidense. El análisis realizado ha revelado que en España existe un fuerte patrón estacional, así como una tendencia constante de manera anual.

Se puede observar en este estudio como en las películas españolas generalmente su estreno suele ser durante los últimos y primeros meses del año, mientras que las fechas de estreno de las películas estadounidenses tienen lugar en los meses de primavera-verano.

Dada la dificultad que conlleva realizar un estudio de una serie estacionalizada, una vez realizada su desestacionalización, se puede contemplar que no hay cambios significativos en los resultados. Pese a que en este último período no ha disminuido la oferta de estrenos de las producciones, la demanda si lo ha hecho. Los motivos de que la demanda haya ido en descenso son múltiples, pero cabría destacar entre ellos la crisis económica que ha atravesado España desde 2008; aunque en los últimos años la crisis está en proceso de recesión y eso también se está empezando a notar en una recuperación de la taquilla. Otro motivo puede ser la gran red de piratería que se encuentra en el país, la cual permite el acceso ha contenido en un corto período después del estreno de las películas; y a los espectadores no les importa esperar un poco más con tal de ver estas producciones de manera gratuita. Finalmente otra razón parece ser las nuevas plataformas que ofertan estas producciones en streaming junto a otro gran catalogo de series y películas, todo por una cuota mensual fija.
Resulta de vital importancia tener en cuenta la diferencia estacional entre el cine español y el estadounidense, pues es un factor muy influyente que -junto a otros factores- supone una desventaja del cine nacional frente al extranjero. Se puede distinguir la supremacía de las majors estadounidenses frente a las productoras nacionales, en especial debido al bajo presupuesto frente a la gran inversión y las grandes campañas publicitarias que emplean las distribuidoras norteamericanas con campañas que captan un gran volumen de público a nivel mundial. Del mismo modo las producciones norteamericanas más grandes realizan eventos en los lugares donde se va a estrenar la película, permitiendo que el público sea partícipe antes de que esta se haya estrenado; mientras que en España estos eventos son de producciones muy concretas, que son las que han conseguido una mayor inversión presupuestaria y por lo tanto se promocionan de manera más proactiva para llegar a conseguir un mayor número de espectadores.

El estudio muestra que el público tiene menos tiempo para acudir a las películas españolas dado al período en el que se estrenan, a diferencia de los estrenos norteamericanos que generalmente coinciden con los períodos en los que los espectadores tienen más tiempo libre para invertir en ocio. Esto podría ser el principal motivo por el cual la taquilla española recauda en menor medida que la norteamericana.

En muchas ocasiones las distribuidoras tienen conflictos de intereses, pues muchas de las distribuidoras españolas al contar con capital norteamericano tienen que decidir si realizar un estreno español que se prevé obtendrá una gran acogida en la taquilla en una fecha en la que está previsto realizarse un estreno de una película estadounidense de la que también se prevé que obtenga una gran acogida en la taquilla. Normalmente cuando ocurre esta situación, las distribuidoras optan por retrasar el estreno español a favor del norteamericano debido a que las majors son las que financian su actividad. Ante esta situación el gobierno español debería realizar alguna modificación para apoyar y fomentar más la producción cinematográfica nacional para conseguir recortar un poco la diferencia con el cine norteamericano y su hegemonía. 
Para que el mercado cinematográfico español pudiese llegar a competir con el mercado norteamericano debería plantearse realizar una internacionalización, buscar el modo en que sus producciones resulten atractivas en todas partes del mundo con el fin de no captar solo espectadores españoles sino por fuera de nuestras fronteras. Pese a que en los últimos años es cada vez más frecuente ver producciones españolas que intentan atraer mayor cantidad de público global aún queda mucho camino por recorrer, pues el número de películas que logran internacionalizar la demanda es muy reducido y estas no pueden llegar a competir con el mercado norteamericano. Por ello las productoras y distribuidoras tendrían que utilizar cada vez más recursos en internacionalizar las producciones españolas y en, cierto modo, cambiar las fechas de estreno y adecuarlas a las fechas en las que la afluencia de público podría ser mayor tal como lo hacen las distribuidoras norteamericanas. Solo así conseguirán poder hacer frente a la gran hegemonía con la que cuenta hoy el cine estadounidense.

Desde otra perspectiva, el Estado podría fomentar que más público acudiese al cine rebajando los precios de las entradas. En varias ocasiones como, por ejemplo, en la Fiesta del Cine o los días del espectador se ha podido comprobar que la recaudación y el número de espectadores por salas aumentan al tener un menor precio de entrada.

\section{Referencias}

Acland, C. (2003). Screen Traffic: Movies, Multiplexes and Global Culture. Durham, USA: Duke University Press.

Ainslie, A., Drèze, X. and Zufryden, F. (2005). Modeling movie life cycles and market share. Marketing Science, 24(3), 508-517.

Augros, J. (2000). El dinero de Hollywood: financiación, producción, distribución y nuevos mercados. Barcelona, España: Paidós Ibérica.
Box, G., Jenkins, G. and Reinsel, G. (1994). Time Series Analysis, Forecasting and Control. New Jersey, USA: Prentice Hall.

Brocwkell, R. and Davis, R. (1991). Time Series: Theory and Methods. New York, USA: Springer.

Chalaby, J. (2006). American Cultural Primacy in a New Media Order. International Communication Gazette, 68(1), 33-51.

Caparrós, A. y Marcenaro, O. (2016). Notas de econometría II. Málaga, España: Universidad de Málaga.

Dadek, W. (1962). Economía cinematográfica. Madrid, España: Ediciones Rialp.

De Vany, A. and Walls, W.D. (1997). The market for motion pictures: Rank, revenue and survival. Economic Inquiry, 35(4), 783-797.

Díaz-González, M. (2016). Política cultural y crisis económica: algunas reflexiones a propósito de la reforma de la Ley del Cine. ICONO, 14(2), 182-203.

Écija, H. (2000). Libro blanco del audiovisual: cómo producir, distribuir y financiar una obra audiovisual. Madrid, España: Grupo Exportfilm.

Einav, L. (2007). Seasonality in the US motion picture industry. RAND Journal of Economics, 38(1), 127-145.

Ellwood, D.W. and Kroes, R. (Ed.) (1994). Hollywood in Europe: Experiences of a Cultural Hegemony. Amsterdam, Netherlands: VU University Press.

Gil, R. (2006). La piratería en España: el caso de la industria musical y del cine. Recuperado de http://www.iese.edu/research/pdfs/OP-07-01. pdf.

González, J.F. (2002). Aprender a ver cine. Madrid, España: Ediciones Rialp.

Harvey, A. (1993). Time Series Models. Hemel Hempstead, England: Harvester Wheatsheaf.

Izquierdo, J. (2007). Distribución y exhibición cinematográfica en España. Un estudio de situación 
del negocio en la transición tecnológica digital (tesis doctoral). Universitat Jaume I, Castellón, España.

Izquierdo, J. (2009). El impacto de la tecnología en la exhibición cinematográfica: el lento camino a la sala digital. Revista Latina de Comunicación Social, 64, 43-56.

Izquierdo, J. (2010). La distribución en el contexto cinematográfico: la consolidación de la hegemonía digital de Hollywood. Área Abierta, 27, 1-15.

Izquierdo, J. (2012). Distribución online de contenidos audiovisuales análisis de 3 modelos de negocio. El Profesional de la Información, 21(4), 385-390.

Martí, F. y Muñoz, C. (2001). Economía del cine y del sector audiovisual en España. Información Comercial Española, ICE: Revista de economía, 792, 124-138.

Marzal, J. y Casero, A. (2007). El desarrollo de la televisión digital en España. La Coruña, España: Netbiblo.

Miller, T. et al. (2005). Global Hollywood 2. London, England: BFI Publishing.

Nowell-Simith, G. and Ricci, S. (Ed.) (1998). Hollywood and Europe: Economics Culture, National Identity 1945-1995. London, England: BFI Publishing.

OAE. (2015). The Circulation of European Films Outside Europe. Strasbourg, France: European Audiovisual Observatory.

Orbach, B. and Einav, L. (2007). Uniform prices for differentiated gods: The case o the movietheater industry. International Review of Law and Economics, 27, 129-153.

Papies, D. and Clement, M. (2008). Adoption of New Movie Distribution Services on the Internet. Journal of Media Economics, 21(3), 131-157.

Pardo, A. (2006). Globalización y americanización: nuevos frentes en la batalla económica y cultural entre Hollywood y Europa. En Montero, J. y Cabeza, J. (Ed.), Por el precio de una entrada (pp. 161-181). Madrid, España: Ediciones Rialp.

Pardo, A. (Ed.) (2007). The Europe-Hollywood Competition: Cooperation and Competition in the Global Film Industry. Pamplona, España: Universidad de Navarra.

Pardo, A. (Ed.) (2010). Europa frente a Hollywood: breve síntesis histórica de una batalla económica y cultural. Pamplona, España: Universidad de Navarra.

Pérez, J. (2013). La tormenta perfecta del cine español: situación de la industria cinematográfica en España. Razón y Palabra, 81. Recuperado de http://www.razonypalabra.org.mx/N/N81/ V81/30_Perez_V81.pdf.

Rubio, A. (2006). La postproducción cinematográfica en la era digital: efectos expresivos y narrativos (tesis doctoral). Universitat Jaume I, Castellón, España.

Segrave, K. (1997). American Films Abroad: Hollywood's Domination of the World's Movie Screens. Jefferson, USA: McFarland.

Simón, S. (2014). El cine español en el contexto de la crisis: tendencias de producción, controversias sobre la piratería e impacto global. Málaga, España: Universidad de Málaga.

Sychowski, P. (2000). Electronic Cinema: The Big Screen Goes Digital. London, England: Screen Digest.

Stokes, M. and Maltby, R. (Ed.) (2004). Hollywood Abroad: Audiences and Cultural Exchanges. London, England: BFI Publishing.

Terry, N., Butler, M. and De'Armond, D.A. (2003). Determinants of the box office performance of motion pictures. Proceedings of the Academy of Marketing Studies, 8(2), 23-27.

Uriel, E. y Muñiz, M. (1993). Estadística económica y empresarial. Teoría y ejercicios. Madrid, España: AC.

Vila Oblitas,J.R., Guzmán-Parra, V.F.y QuintanaGarcía, C. (2012). Análisis de la estacionalidad en el sector cinematográfico: estudio comparativo 
entre la industria extranjera y la española. Investigaciones Europeas de Dirección y Economía de la Empresa, 18(2), 177-182.

Zhang, X., Hou, G. and Dong, W. (2017). Modelling movie attendance with seasonality: evidence from China. Applied Economics Letters, 24(19), 1351-1357. 